DOI https://doi.org/10.30525/978-9934-26-004-9-70

\title{
СОВРЕМЕННЫЕ МЕТОДЫ ВЗАИМОДЕЙСТВИЯ ХУДОЖЕСТВЕННО-ИЗОБРАЗИТЕЛЬНОЙ И ПРОЕКТНО-ДИЗАЙНЕРСКОЙ ПРАКТИКИ
}

\author{
Пилипчук О. Д. \\ кандидат технических наук, \\ доцент кафедры рисунка и живописи \\ Полубок А. П. \\ дочент кафедры рисунка и живописи \\ Киевского национального университета \\ строительства и архитектуры \\ г. Киев, Украина
}

Коммуникативно-информативная система обмена с внешней средой обозначила современные тенденции в изобразительной и проектнодизайнерской практике, которые по своей идейной, конструктивной и функциональной составляющей непосредственно связаны с использованием современных новейших технологий. Характер и степень их взаимодействия формируют направления в современном искусстве, которые строятся на взаимодействии визуального искусства и архитектурной среды с использованием современных технических и программных средств. Отсюда постоянный поиск новых методов с целью получения выразительности в создании новых объектов, с целью создания гармонии между человеком и средой [3]. Например, это может быть объединение изображения, освещения, текста, звука, видео в одном цифровом представлении. (например, мультимедиа, «видеоарт», наноискусство и др.).

Изменение вида образной составляющей пространства мегаполиса в индустриальных зонах и депрессивных районах, привела к новому пониманию пространства для социума, с присутствием фактора парадокса, протеста. Изображение рассматривается как вызов. Визуальное искусство строится на диссонансе к окружающему пространству, но за счет этого, контрастирует и выделяет его из общего окружения. Вызвано, это прежде всего, психологическим фактором - художник стремится выделиться, самоутвердиться, при этом он строит свое творчество на контрасте с окружением (искусство «муралов», современный авангард, арт-объект, арт-дизайн, искусство инсталляции, перфоманс, концептуальное 12 
искусство, «хеппениг», «фристайл» и др.) Любой предмет изобразительного искусства может иметь вид провокационного объекта, что противоречит классическим объективным правилам взаимосвязи искусства и окружения. Соответственно альтернативные идеи, воплощаются в новые возможности формирования среды основанные на методе противоречия формы и содержания. Основные характерные черты - открытость красок, графичность, стилизованность, гротескность изображения, отказ от прямой фигуративности, обращение к искусству комиксов [1]. Например, направление «граффити», характеризующееся открытостью красок, графичностью и стилизованностью выполнения с помощью аэрозольных баллончиков или аэрографа [2]. Или, например, модное направление монументальной живописи, такое как «муралы», которое взяло только внешнюю оболочку исторического явления, далеко отойдя от основ искусства «мурализма», где живопись и архитектура соединялись воедино, повторив лишь сходство в названии и пренебрегая основными принципами изображения характерными для «мурализма» взаимосвязью изобразительного элемента с архитектурным пространством, целесообразностью, образностью, а также гармонией с человеком.

Новизна и нестандартность решений, приоритет замысла над визуальным воплощением характеризуют метод провокационного объекта. В основе которого лежит психология архитектурного пространства, ощущение психологического воздействия, эмоциональнообразного содержания, ироничности, лиризма. Цель - убрать границу между искусством и жизнью, вызвана психологическим фактором и осуществляется посредством создания определенных ситуаций, где среда и изобразительное искусство как событие - игра случайностей.

Понимание произведения искусства как пространственной формы легло в основу метода формирования пространственной среды, построенного на иллюзорных эффектах трехмерных композиций законов объема, цвета, света. Метод носит характер интуитивного, не подлежит логическому и теоретическому пониманию. Основан на чувственноэмоциональном подходе и эмпирических отношениях, чисто субъективных реакций. Зритель сам меняет свое восприятие от изобразительного элемента, в зависимости от условий его созерцания и нахождения в пространстве, воспринимает не глазами, а в соответствии с движением и собственным настроением. Происходит коммуникация по принципу «художник - объект визуального искусства пространственная среда - реципиент». Зритель чувствует вовлеченным себя в уникальное зрелище, при этом колористические эффекты, 
возникшие в технологической связи формы, света и цвета, создают художественное пространство, в котором находится человек.

Возможности монументального оформления, создаваемого с помощью художественных средств, основанных на фантастическом и эмоционально-эмпирическом уровне в абстрактной форме, построенных на ассоциативном методе, с отрицанием реального сюжета, объединяют различные виды изобразительного искусства с трехмерным пространством. Характерные черты этого метода - сочетание цвета и света с художественно-пластическими формами, ассоциативность и образность, при этом осуществляют мощное впечатление на человека. Нужно отметить, что по своей инструментальной составляющей ассоциативный метод подобен одному из популярных методов в дизайне и архитектуре - методу формообразования. Он также основан на создании гармонии пространства с жизнедеятельностью человека. Характеризуется соединением технологических инноваций использованием новейших технологий и материалов с уникальными свойствами футуристической фантазии для воплощения природных форм, эстетичностью, эргономичной функциональностью [4].

Понимание изобразительного искусства как пространства или панорамы, стало возможным с развитием новейших технологий и новых достижений современной науки. Визуальное искусство становится рассчитанным на публичную демонстрацию, оно поглощает зрителя и заставляет жить в нем, при этом рождается пространственный объект, по своей структуре - результат действия. При этом искусство - гибкий, легко приспособленный инструмент, основанный на новом понимании взаимодействия произведения, материала творчества и среды, создает иллюзию альтернативного пространства и новую форму получения информации.

Можно сделать выводы, в XXI в. наметилась тенденция дифференциации в искусстве. Актуализация художественных течений и направлений создает новые идейные направления, а соответственно возможности их воплощения в современной дизайнерско-проектной практике. Это на сегодня является новым качеством выразительных средств массовой коммуникации социально-культурных трансформаций в условиях глобализации мира.

\section{Литература:}

1. Бертолина Дж. Течения в искусстве от импрессионизма до наших дней / пер. с итал. М.С. Тарасова. М.: Омега, 2012. 348 с. 
2. Ефимов А.В., Минервин Г.В., Ермолаев А.П., Шимко В.Т., Щептиков Н.И., Гаврилина А.А., Кудряшев Н.К. Дизайн архитектурной среды: учебник для вузов. М.: Архитектура - С, 2006. 504 с.

3. Пилипчук О.Д., Полубок А.П. Рішення творчого задуму художньо-декоративної форми в залежності від застосованих матеріалів // ScienceRise. DOI: https://doi.org/10.15587/2313-8416.2019.164772

4. Техническая эстетика и дизайн: словарь под общей ред. М.М. Калиничевой. М.: Академический проект: Культура, 2012. 356 с.

DOI https://doi.org/10.30525/978-9934-26-004-9-71

\title{
ТВОРЧІСТЬ ЯК ФОРМА САМОБУДІВНИЦТВА ОСОБИСТОСТІ
}

\author{
Шлемкевич С. Л. \\ кандидат філософських наук, доцент, \\ дочент кафедри філософії, соціології та культурології \\ Національного лісотехнічного університету України \\ м. Львів, Украӥна
}

Реалії сучасного світу викликають динамічні зміни у всіх сферах людської діяльності, актуалізують пошуки нових нетрадиційних шляхів формування та розвитку особистості, яка повинна бути готовою змінюватися, оволодівати новими професіями, ставати більш мобільною у прийнятті рішень. Якщо в минулому цілком виправданим вважалося уявлення щодо процесу формування особистості як процесу накопичення певної сукупності знань та навичок, які забезпечать повноцінне функціонування людини як фахівця-спеціаліста, то сьогодні уявлення про всебічно розвинуту особистість, перш за все, асоціюється із установкою на креативність, на здатність реалізувати творчий потенціал і у цьому вищому злеті творчої енергії втілити всю багатогранність і повноту життя, дарованого Богом, долею, часом. При цьому сутнісним результатом процесу творчості виступає не стільки нова якість дії, скільки ускладнення самого духовного вияву буття, його нові виміри.

Розуміння творчості як сутнісної характеристики людини, як особливої форми вияву духовності, дає можливість вважати творчою не тільки діяльність, що завершується продукуванням «нового», а й таку, головною сферою якої $є$ формування людських якостей, ускладнення культурного і духовного потенціалу особистості, залучення до вищих смислів Буття. Таке трактування певною мірою вступає у протиріччя 3 